\title{
Assessing the Practices of School-based English Mentoring: The Case of Four Government Secondary Schools in West Gojjam Zone
}

\author{
BELAYNEH AMSALU 8 (iD) $\triangle$ \\ Department of English Language and Literature, Faculty of Social Sciences and Humanities, Mekdela Amba University, Ethiopia \\ $\triangle$ Corresponding Author: BELAYNEH AMSALU, E-mail: balezamsalu@gmail.com
}

\begin{tabular}{|c|c|}
\hline ARTICLE INFORMATION & \multirow{10}{*}{$\begin{array}{l}\text { ABSTRACT } \\
\text { The main purpose of this study was to explore EFL teachers' practice on school-based } \\
\text { English mentoring on four selected government secondary schools in West Gojjam } \\
\text { Zone. To put this in to effect, descriptive survey design was used. To collect data } 16 \\
\text { experienced EFL teachers who are assigned to lead the mentoring role and } 36 \text { less- } \\
\text { experienced 'mentee' teachers were selected purposefully from the four educational } \\
\text { settings. In addition, school principals, supervisors and English language department } \\
\text { heads were also used as a source of data. Convenience and purposive sampling } \\
\text { strategies were used to select the sample schools and the teacher participants } \\
\text { respectively. Whereas, comprehensive sampling strategy was used to select principals, } \\
\text { supervisors and English department heads. After the data analysis, the results } \\
\text { indicated that the formal practice of mentoring by EFL teachers was very low. The } \\
\text { literature in the field suggests that less-experienced teachers' learning to teach can be } \\
\text { facilitated through the constructive support and advice of experienced teachers within } \\
\text { a collaborative learning environment. However, this research highlights there is a } \\
\text { loose interaction among the stakeholders of the mentoring practice - mentors, } \\
\text { mentees and school administrators. And finally based on the findings of the study, } \\
\text { some possible suggestions were recommended to responsible bodies. }\end{array}$} \\
\hline Received: February 08, 2021 & \\
\hline Accepted: March 14, 2021 & \\
\hline Volume: 3 & \\
\hline Issue: 3 & \\
\hline DOI: 10.32996/jweep.2021.3.3.1 & \\
\hline KEYWORDS & \\
\hline English Mentoring, Government & \\
\hline Secondary Schools, West Gojjam & \\
\hline Zone & \\
\hline
\end{tabular}

1. Introduction

\subsection{Background of the Study}

As it is known, education plays great role for the development of a nation. That means citizens should be educated so as to bring development to one's country. It is due to this reason that most scholars agree upon the idea that education is a cornerstone for development. Accordingly, Tadesse (2012) as cited in a report on a future search conference says "There is no better ways of achieving development than educating our citizens." This is because the experience of most, if not all, developed nations testify that human resource is an indispensable and irreplaceable tool for development.

Therefore, there cannot be any higher agenda in our country than educating the citizens so as to mobilize them towards economic development. Cognizant of this fact, our country Ethiopia has undergone massive education sector developments in the last couple of decades, and, undoubtedly, remarkable achievements have been scored (Tadele, 2013). In line with this, it is everybody's belief that this massive growth should be complemented by quality education. To this end, the government of Ethiopia is extensively working towards rendering quality education to its citizens. The strategies designed in this regard have started to show good progress. To bring quality education, an involvement of a number of stakeholders is needed rather than leaving it to one party, namely the government, which would be best achieved if done in collaboration.

When we talk about education in general and quality education in particular in Ethiopia, the role that English language plays cannot be oversimplified. It is due to this reason that the report by MOE (1994) discusses "English language has played a central role in the education system of the country since the introduction of modern education at the beginning of the $19^{\text {th }}$ century." To back up this again, the New Education and Training Policy (MOE, 1994) of Ethiopia recognizes English language to be offered as a subject starting from grade one and to be used as a language of instruction in secondary and tertiary levels of education. For

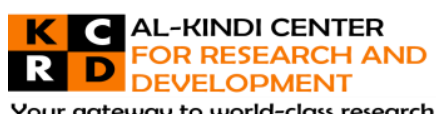

Your gateway to world-class research

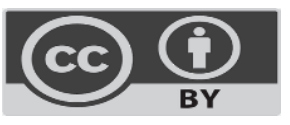

Published by Al-Kindi Center for Research and Development. Copyright (c) the author(s). This open access article is distributed under a Creative Commons Attribution (CC-BY) 4.0 license 
the researcher, English language is like a tyre of a car as the other parts of the car are those different issues which people can do by using the language.

Globally, English language has also established itself as a lingua franca. It has become the language of worldwide communication in media, science and technology, business, academia, politics and so on (MOE, 2003). This calls for the need to produce citizens who can competitively and easily avail themselves to the world arena, which has already become a global village.

In order to meet these demands, it is worth giving due attention to enhancing the quality of English language teachers at all levels of the education ladder in Ethiopia in general and high school English teachers in particular. Nowadays, in the Ethiopian context everyone has no courage to say that all high school English teachers have had the expected language proficiency and pedagogical knowledge, which helps them deliver their content knowledge in the classroom properly. Especially, the problem is seen serious with less-experienced English language teachers. To back up, the School Based English Mentoring Hand Book which was compiled by the MOE $(2012$, p. 2) assures this fact saying "In Ethiopia many teachers of English and their students need support in developing their own language proficiency and in improving their teaching methods." Furthermore, the impact study conducted by Lund University in 2005 and Haramaya University in 2007 on English Language Improvement (ELIP) as cited in MOE (2012) indicates that teachers need intervention to improve their proficiency and pedagogical skills in English. For the investigator, the problem could emanate from gaps in English Mentoring practices by EFL teachers within the school context.

In order to minimize practitioners' lack of English language teaching skills and promote the use of English in Ethiopian schools, practical contributions have been prepared and done by the Federal Democratic Republic of Ethiopia Ministry of Education and other co-workers like the British Council, which works on language and culture (MOE, 2007a; The First Ethiopian Mentor Trainer Team, 2012, p. 2).

School-Based English Mentoring which can be abbreviated as SBEM is among the measures taken. Actually, mentoring has been defined by different scholars and their thought is generally revolved around 'helping others', or it is the support given by those experienced individuals to the less-experienced or novice ones. In education, mentoring refers to the support given by experienced teachers to the less-experienced teachers usually to enhance their professional development. Hence, Malderez (2009) identifies mentoring as "A process crucial to teacher development that focuses on the teachers' ability to succeed in a specific workplace context."

As Haney (1997) typically noted as "a way to develop teaching practices that involve a close relationship between a less experienced person and a more experienced person who provides guidance, advice, support, and feedback." Adapting slightly from Malderez and Wedell (2007) "Mentoring is the support given by one (usually more experienced) colleague for the growth and learning of another." Rhodes and Beneicke; Clutter buck; as cited in Kennedy (2005) have discussed that mentoring often implies counseling and supportive relationship where one partner is novice and the other more experienced. And in the Ethiopian context, mentoring is practiced in schools as it is an important contributing factor for teacher professional development (Daniel, Desalegn \& Girma 2013, p.91).

From these definitions, we can conclude that mentoring is to support and encourage less-experienced teachers to manage their own learning, to maximize their potential, develop their skills, improve their performance, and become the person they want to be. SBEM is, therefore, a kind of help or support given by experienced teachers of English -commonly known as 'mentors' to less-experienced English teachers - 'mentees' usually within the school context, especially to enhance the mentees' professional development.

Even though historically mentoring is originated from Greek Mythology and its notion is rooted in the constructivist philosophy which claims that humans generate knowledge and meaning from an interaction between their experiences and their ideas, nowadays the concept has been spreading in Ethiopia, largely with regard to school-based career training (The First Ethiopian Mentor Trainer Team Hand Book, 2012 p. 8). According to the Hand Book, SBEM is an in-service mentoring which differs in some important ways because it supports in-service development. And it is one element of English Language Improvement Program (ELIP), which is again an element of Teacher Development Program (TDP) as the aim of TDP is to improve the performance of teachers in the classroom and to raise students' achievement and learning thereby improving quality of education (slightly adapted from MOE, 2009b).

\subsection{Statement of the Problem}

Mentoring is a form of personal and professional partnership which usually involves a more experienced practitioner supporting a less-experienced one who is new to the job, organization or profession (Butcher, 2002). And as can be seen in the above section, it is very important for the professional development of teachers, especially for less-experienced teachers. Indeed, different studies assure this fact as well. For example, in the mid-1990s, the American Association of Teacher Education analyzed 
data from a survey of teacher educators, school teachers, university and school administrators, and identified mentoring as the most crucial strategy for professional development of teachers (Anderson, 1992). Besides, research in to professional development has pointed more strategies for up-skilling teachers for which mentoring has been very effective in accomplishing change in teaching and their work (Hargreaves \& Fullan, 2000; Kochan \& Pascarelli, 2003).

Moreover, local researchers like Daniel, Desalegn and Girma (2013 p. 86) who conducted a survey on 'School-based Teacher Professional Development in Addis Ababa' and scholars like Richards \& Farrell (2005 p. 4) all argue that mentoring is the core and number one strategy for professional development of teachers as the idea behind it is mutual sharing of knowledge and experience which is a valuable source of professional growth.

As a result of this, many scholars suggest that EFL teachers should practice mentoring within the school context for mentoring during practice teaching has received a prominence in recent years due to the perceived need for change in the organization of the field experience and make suggestions as to how this might happen (Hennisen, et al.,2011).The first reason for change stemmed from the increasing need for and the recognition of the value of professional learning in natural workplace environment (Bolhuis \& Voeten, 2001); second, the questioning of the practical relevance and applications of theory-based courses that are often blamed for the disconnectedness between university education and field-based teacher training (Kumaravadirelu, 2012; Zeichner, 2010); third the reported professional value of mentoring practices in school-based learning environment (Koc, 2012).

Hence, taking in to account the values of English mentoring within the school context, the GEQIP plan of the MOE (2008) sub component entitled 'In-Service Teacher Education Quality Improvement Program' which targets, among others, providing English language training for teachers of English and developing a cadre of school-based English mentors who will support teachers came in to being, and has been given attention by the concerned bodies of the education sector since the last few years.

In Amhara Regional State, a place where the study is conducted, although the informal way of mutual support among EFL teachers had a long history, the formal school-based English mentoring program was started after three years of the introduction of the program by the Ethiopian Ministry of Education, that is, in 2012 (The First Ethiopian Mentor Trainer Team, 2012). Since then, the Amhara Regional State Education office in collaboration with other co-workers like the British Council has been encouraging the English mentoring program by providing appropriate materials such as SBEM manuals and through giving training to school-based English mentors. And the researcher was among those who took the first mentoring training of secondary school teachers of English. The main reason as said above is that this approach is more appropriate as it develops the skills relevant to teachers' area of teaching by increasing job success, self-confidence and self-esteem and reducing trial and error learning (The Alberta Teachers' Association Handbook, 1998). However, though an effort was made to introduce English mentoring to secondary schools of Amhara Region and encouragement was made to Practitioners to employ it in their schools, to the extent that the researchers' knowledge is concerned, there was no an empirical research that indicated whether or not EFL teachers put in use the mentoring program.

But as I reflect on my observation [as a teacher in different secondary schools] I strongly felt that lack of due attention to SBEM is prevalent in the teaching and learning practices as the presence of factors like most language teachers perceive that teaching is a scheduled activity conducted in private over which they hold away (Brookfield, 1995). It is undeniable that such a problem hampers EFL teachers' professional growth and thereby students' success in achieving the intended language proficiency and put the quality of EFL education in question. So, the inspiration for this study partly comes from the recognition of this problem.

Regarding to empirical researches, an attempt was made to explore on the school-based mentoring practices and challenges that affect its implementation by two local researchers although their focus and context is different from the present study. For example, Solomon (2001) conducted a survey entitled 'Some Insights into the Mentoring Role of High School Teachers at Addis $A b a b a^{\prime}$ and identifies that the cooperating teachers (mentors) do not seem to be successfully discharging their mentoring duties. For the study, shortage of time, lack of enthusiasm and lack of mentoring skills on the part of mentors are some of the factors noted.

Another researcher Hailu (2006) made a survey on 'Factors Affecting School-Based Mentoring's Implementation at Kotebe College of Teacher Education and St. Mary's University Colleges' Practicum'. By using questionnaire and interview as primary data collection instruments, the study revealed that lack of assistance from school administrators, considering mentoring as an extra responsibility on the part of school-based mentors and mentors' inability to get training on mentoring skills as some of the factors that hinder the SBM.

Therefore, the above arguments on the relevance of mentoring in enhancing English language instruction and the researchers' personal experience about the mentoring program inspired him to develop an interest in investigating EFL teachers' practice of mentoring on some selected comprehensive secondary schools of West Gojjam Zone in Amhara Regional State. This is because a 
study to look in to practices and challenges will have practical implications for examining gaps and identify areas of intervention that eventually lead to promote EFL teachers' SBEM practices.

\subsection{Objectives of the Study}

\subsubsection{General Objective}

The general objective of the study was to investigate EFL teachers' practice on School Based English mentoring on some selected government comprehensive secondary schools in West Gojjam Zone.

\subsubsection{Specific Objectives}

The specific objectives of this study were the following:

1. To explore the practices of School Based English Mentoring in secondary schools.

2. To assess the provisions in place that support the SBEM program at school level.

\subsection{Research Questions}

Based on the above objectives, this research answering the following research questions:

1. To what extent do English language teachers employ School Based English Mentoring (SBEM)?

2. What provisions are in place to support the School Based English Mentoring program practices at school level?

\subsection{Significance of the Study}

The study will give some idea related with EFL teachers' practice on SBEM. More specifically, the study may have the following significance: First, the study may increase the awareness of school administrators and other concerned bodies of what should be done to promote SBEM. Second, this study again may give some crucial information for those who are working on the professional development of English language teachers like teacher trainers and educators who have a role in teaching and training to improve English language teachers' profession. Third, by revealing the gaps in the practices, it may give an insight for the program's main actors - EFL mentor and mentee teachers to improve the implementation of SBEM for their professional development. It also helps them to be aware of the prevailing beliefs and attitudes that may scholars have so that they can rationalize their practices towards the existing working contexts and trends. Finally, since the issue of this study touched only the smallest part of variables of English mentoring within the school context, the study can also be used as a spring board or an initial source for researchers who want to conduct further research up on this portion.

\subsection{Delimitation of the Study}

Since mentoring is broad and has different practices, it might be very difficult to get in touch all the practices in this study. Therefore, the researcher delimited his study on the most common areas or values of mentoring involved in EFL teachers' dayto-day activities. Further, the study was limited to examining EFL teachers' practice on School Based English Mentoring (SBEM) on four selected government comprehensive secondary schools of West Gojjam Zone in Amhara regional state for manageability and resources.

\subsection{Operational Definitions}

Practice - the implementation of a program or a given task for a particular purpose.

Challenges - factors or problems that affect the practice of a program in a special occasion.

School Based English Mentoring - is a kind of in - service mentoring which targets to support in - service professional development of English foreign language teachers (The First Ethiopian Mentor Trainer Team Handbook, 2012 p. 8).

Comprehensive Secondary Schools - schools which comprise $9^{\text {th }}$ to $12^{\text {th }}$ grade level students.

(MOE, 1998).

Mentoring - all the things a mentor does to support their own and their colleagues' learning.

English School-Based Mentor - an experienced teacher who is an integral part of the teacher induction process through his or her work with less-experienced teachers (Collins \& O' Brien, 2003: p. 218-219) and/or a colleague who is different from his/her peers only in that $\mathrm{s} /$ he has had special training on mentoring which has helped him/her understand how teachers learn and how to support that learning in schools.

Mentee - the teacher colleague who is learning the mentor aims to support and has less experience of teaching (Collins \& $\mathrm{O}^{\prime}$ Brien, 2003: p. 244). In this study, terms like novice teacher, mentee and less-experienced teacher are used interchangeably. In addition, mentor and experienced teacher are also used one in place of another. 


\section{Methodology}

In this chapter, the research design, research participants, sampling methods and procedures, instruments, data collecting procedures as well as data analysis techniques are described.

\subsection{Research Design}

This study aimed to investigate EFL teachers' practice on SBEM, descriptive survey design involving both quantitative and qualitative data was employed. The researcher used this design as it helps to show immediate states of phenomenon (Selinger \& Shohamy, 1989). The quantitative approach used for its potential to provide a lot of information. The qualitative aspect, on the other hand, was employed for two reasons. One, to complement the quantitative data and the other is to address issues raised in answering some of the research questions which could be possible only through qualitative approach.

\subsection{Research Participants}

EFL teachers of the four selected comprehensive secondary schools of West Gojjam Zone by the year 2019/2020 were participants of the study. In addition, school principals, supervisors and English language department heads were used as participants of this study. The researcher included the aforementioned participants as he believed that these participants help get the relevant information needed for the study.

\subsection{Sampling Techniques and Procedures}

According to the head of Zonal education office, in West Gojjam Zone, there are nine Comprehensive secondary schools. Of these, Dembecha comprehensive secondary school, Jiga comprehensive secondary school, Quarit comprehensive secondary school and Abay Minch comprehensive secondary school were included as samples for this study. The researcher used convenience sampling strategy to select these schools.

With regard to participants of the study, those EFL mentor and mentee teachers of the four schools were included purposefully. Generally, a total of 16 mentor and 36 mentee EFL teachers were selected for the purpose of the study. In addition, by using comprehensive sampling strategy school principals, English language department heads and supervisors of the pre-described schools were informants in order to get in-depth information about the issue.

\subsection{Instruments of Data Collection}

So as to collect the necessary data for this study, two types of data collection tools namely; questionnaire and interview were employed. The instruments were developed and adapted in which some items were designed by the researcher and some others were modified from the Alberta Teachers' Association Handbook (1998). Based on the feedbacks, some items were completely discarded and some others were modified.

\subsection{Procedures of Data Collection}

The data were collected in convenient time for all teachers, school principals, English department heads and school supervisors as it might affect the accuracy of the data. Besides, the researcher gave a brief orientation for the participants of the study about the purpose of the research. In addition, the researcher clarified any possible inquiry the respondents raised while they were filling the questionnaire.

\subsection{Methods of Data Analysis}

The data collected from the questionnaires and the semi-structured interviews were analyzed using quantitative and qualitative data analysis methods. This means, the quantitative data which were collected from questionnaire were tabulated and descriptive statistics such as frequency and percentage were used for the numerical interpretation. On the other hand, the qualitative data which were collected through the interview and open ended questionnaire items were analyzed thematically and transcribed qualitatively along with the quantitative data.

\subsection{Ethical Issues}

For the current research, some crucial points were taken in to account. First, the purpose of the study was explained to the participants and the researcher asked their consent before administering the questionnaire and interview. The researcher also informed his participants that the information they provided would only be used for the purpose of the study. Accordingly, the researcher used the information he gained from his participants only for the study purpose. In addition, the researcher ensured confidentiality by making the participants anonymous. 


\section{Results and Discussion}

\subsection{Results}

\subsubsection{Analysis of Mentors' and Mentees' Background Information}

Table 2: Analysis of EFL Mentor and Mentee Teachers' Demography Based on Their Place of Work (School) and Sex.

\begin{tabular}{|c|c|c|c|c|c|c|}
\hline \multirow[t]{3}{*}{ Schools } & \multicolumn{6}{|l|}{ Sex } \\
\hline & \multicolumn{2}{|l|}{ Male } & \multicolumn{2}{|c|}{ Female } & \multicolumn{2}{|l|}{ Total } \\
\hline & Mentor & Mentee & Mentor & Mentee & Mentor & Mentee \\
\hline Dembecha & 4 & 9 & 1 & 1 & 5 & 10 \\
\hline Jiga & 4 & 5 & 0 & 3 & 4 & 8 \\
\hline Quarit & 3 & 4 & 0 & 2 & 3 & 6 \\
\hline Abay Minch & 4 & 11 & 0 & 1 & 4 & 12 \\
\hline Total & 15 & 29 & 1 & 7 & 16 & 36 \\
\hline Percentage & $93.75 \%$ & $80.55 \%$ & $6.25 \%$ & $19.44 \%$ & $100 \%$ & $100 \%$ \\
\hline
\end{tabular}

As it can be seen above, of the four selected schools, there were a total of 16 mentor EFL teachers. Of these, 15 (93.75\%) were male mentors and only 1 (6.25\%) was female mentor. This showed that females' participation in mentoring others within the four educational settings is low. Similarly, from 36 sampled mentees of the four schools, 29 (80.55\%) were males whereas 7 (19.44\%) were females. Generally, a total of 52 (16 mentors and 36 mentees) were participants who were selected purposefully from the four pre described comprehensive secondary schools. This brings us to the following additional table which shows the distribution of EFL mentor and mentee teacher respondents in terms of age, teaching experience and educational qualification.

Table 3: Distribution of EFL Mentor and Mentee Teacher Respondents in terms of Age,Teaching Experience and Educational Qualification

\begin{tabular}{|c|c|c|c|c|c|}
\hline \multirow[t]{2}{*}{ No } & \multirow[t]{2}{*}{ Variables } & \multicolumn{2}{|c|}{ Mentors } & \multicolumn{2}{|c|}{ Mentees } \\
\hline & & ${ }^{*} \mathrm{~F}$ & $* \%$ & $\mathrm{~F}$ & $\%$ \\
\hline \multirow[t]{6}{*}{1} & \multicolumn{5}{|l|}{ Age } \\
\hline & $20-25$ years & 0 & 0 & 2 & 5.55 \\
\hline & $26-30$ years & 1 & 6.25 & 32 & 88.88 \\
\hline & $31-35$ years & 3 & 18.75 & 2 & 5.55 \\
\hline & $\geq 36$ years & 12 & 75 & 0 & 0 \\
\hline & Total & 16 & $100 \%$ & 36 & $100 \%$ \\
\hline \multirow[t]{7}{*}{2} & \multicolumn{5}{|l|}{ Teaching Experience in Years } \\
\hline & $0-2$ & 0 & 0 & 10 & 27.77 \\
\hline & $3-5$ & 0 & 0 & 26 & 72.22 \\
\hline & $6-8$ & 1 & 6.25 & 0 & 0 \\
\hline & $9-11$ & 4 & 25 & 0 & 0 \\
\hline & $\geq 12$ & 11 & 68.75 & 0 & 0 \\
\hline & Total & 16 & $100 \%$ & 36 & $100 \%$ \\
\hline \multirow[t]{5}{*}{3} & \multicolumn{5}{|l|}{ Educational Qualification } \\
\hline & College Diploma & 0 & 0 & 0 & 0 \\
\hline & First Degree & 16 & $100 \%$ & 36 & $100 \%$ \\
\hline & Master's Degree & 0 & 0 & 0 & 0 \\
\hline & Total & 16 & $100 \%$ & 36 & $100 \%$ \\
\hline
\end{tabular}

$* \mathrm{~F} \Rightarrow$ Frequency $\quad * \% \Rightarrow$ Percentage

As table 2 vividly shows, the majority of mentors 12(75\%) were 36 years and above. Besides, a portion of them (18.75\%) were in the age range of $31-35$ years. It is also important to note that only 1 (6.25\%) mentor was found in the age range of $26-30$ years. On the other hand, out of the total of 36 mentee respondents, the majority of them $32(88.88 \%)$ were found in the age range of $26-30$ years. In addition, a common number of mentee respondents, that is, (5.55\%) were in the age ranges of $20-25$ and 31 - 35 years. Therefore, the data show that (93.75\%) of the mentors are above 30 years from the four selected comprehensive secondary schools whereas (94.75\%) of mentee respondents are below 31 years. 
Table 2 also depicts the current teaching experience of both mentors and mentees. Hence, the majority of mentor respondents (68.75\%) have taught English for 20 years and above. However, (25\%) and only a mentor (6.25\%) served in between 9 - 11 and 6 - 8 years respectively. Similarly, table 2 also shows the mentee respondents' teaching experience. Thus, the majority of them (72.22\%) have found in the teaching experience year range of $3-5$. On the other hand, $27.77 \%$ have taught in between $0-$ 2years.

Moreover, the data in table 2 reveal that all EFL mentors 16 (100\%) and mentees 36 (100\%) who have been teaching at the four selected comprehensive secondary schools were first degree holders though the data gained via informal discussions from the school principals and English language department heads show that there are few (3 out of 16) mentor teachers who are currently engaged in doing their Master's program in teaching English as a foreign language.

\subsubsection{General Experiences of Respondents on English Mentoring program practices}

Under this portion, results of the mentors' and mentees' responses for the questionnaire items on the practices of school based English mentoring program are presented alongside the results gained from the interview items. Mentoring teachers' responses concerning their experiences on the mentoring program practices is presented first in the continuation of mentees' responses.

\subsubsection{Analysis Result of English Mentor Teachers' Response on the Psychological and Instructional Mentoring Practices}

In the mentor teachers' questionnaire, sampled mentor teachers were asked to rate items using five point rating scales: Very Often (5), Often (4), Sometimes (3), Rarely (2) and Never (1). The results of the analysis of the data obtained from the items are presented in the following table:

Table 4: Analysis Result of Mentor Teachers' Responses on School Based English Mentoring Program Practices

\begin{tabular}{|c|c|c|c|c|c|c|c|c|c|c|c|}
\hline \multirow[t]{3}{*}{ No } & \multirow[t]{3}{*}{ Items } & \multicolumn{10}{|c|}{ Respondents' response } \\
\hline & & \multicolumn{2}{|c|}{$\begin{array}{l}\text { Very } \\
\text { Often }\end{array}$} & \multicolumn{2}{|c|}{ Often } & \multicolumn{2}{|c|}{ Sometimes } & \multicolumn{2}{|c|}{ Rarely } & \multicolumn{2}{|c|}{ Never } \\
\hline & & *F & $* \%$ & $\mathrm{~F}$ & $\%$ & $\mathrm{~F}$ & $\%$ & $\mathrm{~F}$ & $\%$ & $\mathrm{~F}$ & $\%$ \\
\hline 1 & $\begin{array}{l}\text { I share my personal experiences to } \\
\text { my mentee/s/ in formal meetings. }\end{array}$ & 0 & 0 & 0 & 0 & 5 & 31.25 & 11 & 68.75 & 0 & 0 \\
\hline 2 & $\begin{array}{l}\text { I inspire and motivate my } \\
\text { mentee/s/. }\end{array}$ & 0 & 0 & 0 & 0 & 6 & 37.5 & 10 & 62.5 & 0 & 0 \\
\hline 3 & $\begin{array}{l}\text { I support my mentee/s/on subject } \\
\text { matter issues via formal discussions } \\
\text { in the school. }\end{array}$ & 0 & 0 & 0 & 0 & 3 & 18.75 & 12 & 75 & 1 & 6.25 \\
\hline 4 & $\begin{array}{l}\text { I support my mentee/s/ to use a } \\
\text { variety of teaching strategies } \\
\text { according to the different learning } \\
\text { objectives. }\end{array}$ & 0 & 0 & 0 & 0 & 4 & 25 & 12 & 75 & 0 & 0 \\
\hline 5 & $\begin{array}{l}\text { I have made observations and } \\
\text { provide feedback to my mentee/s/ } \\
\text { using different feedback strategies. }\end{array}$ & 0 & 0 & 0 & 0 & 6 & 37.5 & 10 & 62.5 & 0 & 0 \\
\hline 6 & $\begin{array}{l}\text { I give professional assistance to my } \\
\text { mentee/s/ on student assessment. }\end{array}$ & 0 & 0 & 3 & 18.75 & 8 & 50 & 5 & 31.25 & 0 & 0 \\
\hline 7 & $\begin{array}{l}\text { I support my mentee/s/ on } \\
\text { classroom management skills. }\end{array}$ & 0 & 0 & 0 & 0 & 5 & 31.5 & 9 & 56.25 & 2 & 12.5 \\
\hline 8 & $\begin{array}{l}\text { I support my mentee/s/ on how to } \\
\text { assist students with special needs. }\end{array}$ & 0 & 0 & 0 & 0 & 2 & 12.5 & 9 & 56.25 & 5 & 31.25 \\
\hline 9 & $\begin{array}{l}\text { I instruct my mentee/s/ on lesson } \\
\text { planning. }\end{array}$ & 0 & 0 & 1 & 6.25 & 11 & 68.75 & 4 & 25 & 0 & 0 \\
\hline 10 & $\begin{array}{l}\text { talk about useful books, } \\
\text { periodicals and journals with my } \\
\text { mentee/s/. }\end{array}$ & 0 & 0 & 0 & 0 & 3 & 18.75 & 8 & 50 & 5 & 31.25 \\
\hline
\end{tabular}

$$
{ }^{*} \mathrm{~F} \Rightarrow \text { Frequency } \quad * \% \Rightarrow \text { Percentage }
$$


As pointed out by Gold (1996) it is important that less-experienced (mentee) teachers should be advised and supported psychologically meant to improve their feelings about themselves, to enhance their capacity to cope with stress and to be better motivated and develop positive attitude towards their teaching career. As can be seen from table 3, item 1 and 2 assess to what extent mentor teachers perform these practices. Hence, for item 1 most of the EFL mentor teachers of the aforementioned schools $(68.75 \%)$ confessed that they meet and share their personal experiences with their mentee/s/ rarely. While $31.25 \%$ of them believed that they meet their mentee/s/ and tell their experiences only sometimes. Similarly, when they were asked to know how frequently they inspire and motivate their mentee/s/, majority $10(62.5 \%)$ and a portion $6(37.5 \%)$ replied that they rarely and sometimes did it respectively. In addition, when mentors were asked to know whether they make formal discussions usually to help the mentee/s/ on subject matter issues in the school so that they can achieve professional learning objectives (item 3), majority $12(75 \%)$ of the mentor respondents replied that they did it rarely. Whereas, $3(18.75 \%)$ confirmed that they have sometimes made discussions formally. Besides, it is also better to note that there was a mentor (6.25\%) who has never made formal discussions on the pre described issue after all. Likewise, when mentors were asked to know how far they assist their mentee/s/ in relation to the different methods to be used across the different language objectives (item 4), majority (75\%) of the respondents replied as if they have done it rarely. However, the rest $25 \%$ confirmed as though they sometimes did it.

Moreover, the interview results collected from the mentors, English language department heads, school supervisors and principals affirmed the above fact. For example, both mentor respondents and the English language department heads assured as if the formal practice of English mentoring is low. When mentors were asked to reply for the question 'How often do you support the less-experienced teachers who are assigned to you?' they replied saying only rarely. An English language mentor further added the following point to the issue after describing that the question was really challenging for him.

Though I informally support the less-experienced English teachers any time when they asked me, I have no full confidence to say that I have always practiced the mentoring program formally as I don't have been given regular time schedules to assist the less-experienced teachers and the presence of the lack of appropriate follow up to the program by the concerned bodies via incentives and facilities. (Mentor 1)

In line with this, English language department heads when asked 'Do you think that English language teachers in your school practice the school based mentoring in a regular basis?', replied almost in a similar fashion that teachers are not in a position of practicing it in a regular basis as it were in 2012 and 2013 academic years, which were the early years of the start of the program. For example one of the English language department heads described his view in the following ways:

Now, I'm afraid to say that English language teachers practice the mentoring program regularly in our school. But when I was down at elementary school, as I was teaching there, I was a mentor and I knew there was the practice better than this. That is, once per a week we English teachers gathered together and raised an issue, perhaps a problem, be it be subject matter or pedagogical and discussed upon it. Finally, after we had reached at one central point, we departed. When I came here, there is the mentoring program in principle and even each year mentees have been identified and mentor teachers have been appointed but both of them lack interest and motivation to come together and help one another. Even I haven't seen the school motivating and giving ongoing support to the mentoring teams besides giving a certain orientation for them once at the beginning of the academic year. (Head 1)

In addition to the above interviewees' facts, school principals and supervisors were also asked to respond their views regarding to the frequency of the mentoring practices by teachers of English language. Though 2 out of 4 supervisors and 1 out of 4 principals first argued as if there were consistent English mentoring practices once per a week and/or sometimes once within two weeks; the rest 2 supervisors and 3 principals all argued that the current mentoring practice by practitioners are not satisfactory due to different factors, they noted, like lack of motivation from both mentors and mentees side, lack of mentoring skill - which is typical to some of the mentors in their schools and lack of mentees' interest to ask questions when they have encountered gaps in their teaching experience as some mentees do not have an intention to continue teaching to the long run. Even those who first argued against the above 2 supervisors and 3 principals finally confessed their distress upon the current English mentor and mentee teachers' structured mutual support by detailed probing questions.

Moreover, super 1 responded saying that even though it is difficult to say it is effective or not without formal research, he believed that there are some gaps and the effort of stakeholders' is getting weaker and weaker when compared to the previous years.

Prior studies show that observing and providing feedback to the less-experienced teachers is one of the responsibilities which mentors should perform for mentees in order to soar to new heights of professional growth and competence. However, in relation to the question raised for mentors about observations and feedback provision (item 5), $62.5 \%$ of them suggested that 
they have made observations and provide feedback to their mentee/s/ by using different feedback strategies only rarely, while small number of mentors $37.5 \%$ replied as if they sometimes did it. This indicates how far less-experienced teachers in the selected schools did not get constructive comments on their very important activities.

As per the literature, less-experienced teachers, as they have relatively less expertise, should be assisted regularly with basic issues like evaluating students' progress, organization of class work, providing for individual variations, classroom management, content knowledge, instructional strategies and finding and developing educational resources though these problems are not peculiar to beginning teachers and are in fact the problems of teachers in general (Veenman, 1984).

As indicated in table 4 item 6 , only $18.75 \%$ of the EFL mentor teachers responded saying 'often' that they support their mentees in how to asses students, whereas, $50 \%$ of the mentors and $31.25 \%$ answered 'sometimes' and 'rarely' respectively.

Regarding the support made on classroom management techniques by mentors(item 7), more than half $56.25 \%$ and only $31.25 \%$ responded that they did it 'rarely' and 'sometimes' respectively. Even 2 (12.5\%) answered as if they did not do it totally. To what extent you assist your mentee/s/ so that they can address the different needs' of their students were another mentoring issue raised for mentors (item 8). Here again, while $56.25 \%$ and $31.25 \%$ responded saying 'rarely' and 'never' respectively, only 2 (12.5\%) replied that they aware their mentee/s/ how to assist students with special needs only sometimes.

Parallel to this, mentor teachers were also asked to respond how frequently they guide their mentee/s/ to plan their lessons well. While this practice is implemented frequently by a single mentor, others $68.75 \%$ and $25 \%$ responded as though they did it 'sometimes' and 'rarely' respectively. The last item in this group is regarding to discussions on useful books, periodicals and journals with less-experienced teachers that item 10 displays the data obtained from the mentors. Though this activity is sometimes practiced by $18.75 \%$ of the mentor teachers, it is a rare practice for $50 \%$ of them. Yet, $31.25 \%$ explained that they never did it after all.

In general, regarding the psychological and instructional supports given by mentor teachers, the mentors' responses show that the mentoring practice is very low. In fact, it seems that the proper practice is almost non-existent in those four educational settings.

\subsubsection{English Mentee Teachers' General Experience on the Mentoring Practices}

Like that of mentors, sampled mentee teachers were asked to rate items using five point rating scales in the mentees' questionnaire: Very often (5), Often (4), Sometimes (3), Rarely (2) and Never (1). The results of the analysis of the data obtained from the items are presented as follow:

Table 7: Mentee Teachers' Responses Concerning to TheirGeneral Experience on School Based English Mentoring Program Practices

\begin{tabular}{|c|c|c|c|c|c|c|c|c|c|c|c|}
\hline \multirow[t]{3}{*}{ No } & \multirow[t]{3}{*}{ Items } & \multicolumn{10}{|c|}{ Respondents' Response } \\
\hline & & \multicolumn{2}{|c|}{ Very often } & \multicolumn{2}{|c|}{ Often } & \multicolumn{2}{|c|}{ Sometimes } & \multicolumn{2}{|c|}{ Rarely } & \multicolumn{2}{|c|}{ Never } \\
\hline & & ${ }^{*} \mathbf{F}$ & $* \%$ & $\mathbf{F}$ & $\%$ & $\mathbf{F}$ & $\%$ & $\mathbf{F}$ & $\%$ & $\mathbf{F}$ & $\%$ \\
\hline 1 & $\begin{array}{l}\text { My mentor shares me his/her } \\
\text { personal experiences in formal } \\
\text { meetings. }\end{array}$ & 0 & 0 & 2 & 5.55 & 9 & 25 & 25 & 69.44 & 0 & 0 \\
\hline 2 & $\begin{array}{l}\text { I have been encouraged by my } \\
\text { mentor about teaching. }\end{array}$ & 0 & 0 & 0 & 0 & 6 & 16.66 & 22 & 61.11 & 8 & 22.22 \\
\hline 3 & $\begin{array}{l}\text { I have received guidance from my } \\
\text { mentor on subject matter issues. }\end{array}$ & 0 & 0 & 0 & 0 & 10 & 27.77 & 23 & 63.88 & 3 & 8.33 \\
\hline 4 & $\begin{array}{l}\text { My mentor formally guides me to use } \\
\text { appropriate methods of teaching for } \\
\text { the different contents to be taught. }\end{array}$ & 0 & 0 & 0 & 0 & 11 & 30.55 & 20 & 55.55 & 5 & 13.88 \\
\hline 5 & $\begin{array}{l}\text { I have received helpful feedback from } \\
\text { my mentor after observations. }\end{array}$ & 0 & 0 & 0 & 0 & 7 & 19.44 & 28 & 77.77 & 1 & 2.77 \\
\hline 6 & $\begin{array}{l}\text { My mentor supports me on } \\
\text { classroom management skills. }\end{array}$ & 0 & 0 & 0 & 0 & 4 & 11.11 & 22 & 61.11 & 10 & 27.77 \\
\hline 7 & $\begin{array}{l}\text { My mentor instructs me on ways of } \\
\text { assisting students with special needs. }\end{array}$ & 0 & 0 & 0 & 0 & 3 & 8.33 & 12 & 33.33 & 21 & 58.33 \\
\hline
\end{tabular}




\begin{tabular}{|c|c|c|c|c|c|c|c|c|c|c|c|}
\hline 8 & $\begin{array}{l}\text { I have received guidance on lesson } \\
\text { planning from my mentor. }\end{array}$ & 0 & 0 & 0 & 0 & 21 & 58.33 & 15 & 41.66 & 0 & 0 \\
\hline 9 & $\begin{array}{l}\text { My mentor discusses with me on } \\
\text { useful books, periodicals and } \\
\text { journals. }\end{array}$ & 0 & 0 & 0 & 0 & 12 & 33.33 & 22 & 61.11 & 2 & 5.55 \\
\hline
\end{tabular}

$$
{ }^{*} \mathrm{~F} \Rightarrow \text { Frequency } * \% \Rightarrow \text { Percentage }
$$

The first two items in the mentees' questionnaire were asked to generate data from them for the psychological support they received. Therefore, as indicated in table 5, more than half $(69.44 \%)$ of the sampled mentee respondents' response for item number 1 showed that rarely, does their mentors hardly share them their personal experiences in meetings. Whereas, $25 \%$ and $5.55 \%$ of the respondents replied that they meet with their mentors and share their experiences 'sometimes' and 'often' respectively. Likewise, for the item which reads 'I have been encouraged by my mentor', $6(16.66 \%)$ replied as if they have sometimes been encouraged. Whereas, the rest $22(61.11 \%)$ and $8(22.22 \%)$ responded that they have rarely and never been encouraged by their assistants with in the school.

Parallel with this, sampled less-experienced English language teachers were asked to know whether they were supported with formal discussions upon the different contents to be taught (item 3). Here again, while a portion of respondents (27.77\%) responded 'sometimes', majority (63.88\%) and 2(8.33\%) replied saying 'rarely' and 'never' respectively. The forth item was to see if their mentors recommended mentee teachers appropriate instructional strategies in line with the different language contents. Accordingly, more than half $55.55 \%$ of the respondents indicated that this was a rare practice and $13.88 \%$ of them expressed that their mentors almost never did this. Whereas, $30.55 \%$ of the mentees said that their mentors sometimes guide them of the appropriate instructional methods.

In addition, for the item that reads 'I have received helpful feedback from my mentor after observations' (item 5 in the table above), most of the mentee respondents $77.77 \%$ replied that they have rarely received feedback from their mentors after observations. On the other hand, $19.44 \%$ of the mentee respondents responded saying that they have occasionally received feedback from their mentors after observations. It is also better to note a single mentee (2.77\%) who replied that constructive comments have never been given by his assistant.

Therefore, from the above findings it can be realized that mentees of the sampled schools have not been shaped with constructive comments of experienced teachers frequently. On the contrary, different scholars agreed with the notion that mentees' activities like their lesson plans, their actual teaching in the classroom - their method of teaching, classroom management skills and presentation style should be observed regularly and appropriate feedback should be given orally or in written form by those who have greater expertise on that field so that less-experienced teachers can be shaped and learned better than what they had before. That is why Little (1990) has reported that a mentor's constructive feedback allows opportunities for less-experienced teachers to reflect and improve teaching practices.

Concerning the advice given by mentor teachers on classroom management skills (item 6), while only $11.11 \%$ replied that their mentors occasionally did it, the majority (61.11\%) of mentee respondents said their mentors rarely gave such activities. The rest $27.77 \%$ stated that their mentors never assisted them on how to manage the students well in the classroom.

When asked to see how far mentees have been advised so that they can address the interests of students with special needs (item 7), a portion $33.33 \%$ and majority $58.33 \%$ of the mentee respondents responded that their mentors did this practice only rarely and did not do it after all respectively. But it is also better to note that only $3(8.33 \%)$ replied that their mentors sometimes did it. For the eighth item in this group, majority $58.33 \%$ of the mentees stated as their mentors occasionally held discussions on lesson planning, whereas, others $41.66 \%$ confirmed that their mentors did it only rarely. At last less-experienced teachers were asked to reply whether their mentors discussed them some important books, periodicals and journals formally in the school. Hence, while $12(33.33 \%)$ responded that their mentors sometimes did it, the rest $22(61.11 \%)$ and $2(5.55 \%)$ replied as though this activity is practiced rarely and sometimes.

Besides, the interview result which was gained from mentees pointed similar findings with the above facts. That is, mentees when asked 'How often have you been supported by your mentor in your school formally?' surprisingly, all replied saying 'rarely'. Moreover, almost all equally described as if they could not get much support and encouragement in a formal way since their mentors are not willing to do so. For example, one of the mentee interviewees said:

I often want to listen and learn many things from my mentor in particular and from experienced teachers in general about the different language contents to be taught, the teaching methods they have used and 
everything that they passed through. But experienced teachers are not all in all voluntary to do so. (Mentee

1)

Similarly, in the interview held with mentees, it was understood that mentors were reluctant to help the less-experienced teachers. Mentees when asked 'Does your mentor eager to help you when you are in need of help?' almost all bitterly explained that their mentors most of the time were not voluntary for help. As to them, even some of the mentors lack confidence to tell them something in the form of black and white. Moreover, they added, some others seem voluntary for help but they did not want to tell them all things openly from the bottom of their heart and even they made themselves off as they were busy. Perhaps, this occurred due to lack of know-how and mentoring skills which are most commonly gained through on-going training.

These results in general indicate that less-experienced English language teachers are not being assisted much with psychological and instructional supports by mentors. As per the results observed, the practice is almost non-existent, which is consistent with the result gained from mentors and other concerned bodies above. However, mentees/less-experienced teachers/ need to be supported regularly to improve their professional growth so that formal discussions on the subject matter, pedagogical issues and about teaching in general are useful means or tools to improve their practice in the course of their career (Feimen - Nemser, 2001).

\subsection{Discussion}

There are many aspects that can be addressed and when it comes to how far SBEM is practiced and the constraints which limit it not to be held well. Therefore, in this section, the researcher discussed the findings and results that were presented in the above portion in line with the pre-described research questions. Hence, for ease communication, he found it better to deal with the aforementioned critical points that he was curious about under the following two themes: status of SBEM program in the four sampled schools, and stakeholders' contributions to enhance the SBEM program.

\subsubsection{Status of SBEM Practices in the Four Sampled Schools}

Without doubt, it might be time consuming and costly to effectively run programs like mentoring within the school context. Different research studies, however, provide some evidence that guiding and supporting less-experienced teachers /mentees/ provide valuable professional development for both less-experienced and experienced /mentor/ teachers. Danielson (1999), for example, found that mentoring fosters the professional development of the practitioners of the program; especially the lessexperienced teachers /mentees/ for it helps them face new challenges through reflective activities and professional conversations. In addition, Scott (1999) points out as though the value of mentoring were not limited only to the professional development of those who practice it. Rather, the researcher has concluded that the perceived benefits of mentoring went beyond this and could be affective as well since mentoring enabled mentors to receive respect, develop collegiality and profit from the mentees' fresh ideas and energy.

In order the above things to happen, mentors need to perform different functions or activities to address the needs of lessexperienced teachers /mentees/ for they are entitled to get professional assistance and advice by a mentor selected from senior and experienced members of the teaching staff in their schools (MOE, 2004).

As stated in the CPD guideline (MOE, 2004), mentors are in charge of providing personal support and professional assistance to mentees. They also have to engage in discussions and keep records on all completed professional development activities, and they are also required to evaluate the activities and assignments accomplished by mentees and check the progress they make in their professional career. However, the result gained by both questionnaire and interview items revealed that the deliberate support given for EFL mentees by mentors regarding to the different activities is low. For example, when EFL mentor teachers of the four schools asked to reply how far they share their personal experiences to their mentee/s/ via formal discussions in the school, (item 1 in table 4), majority of them (68.75\%) confessed that they meet and share their personal experiences with their mentee/s/ rarely, while $31.25 \%$ of them believed that they meet their mentee/s/ and tell their personal experiences sometimes only. Similarly, when they were asked whether they make formal discussions usually to help their mentee/s/ on both subject matter in their schools, majority (75\%) of the EFL mentor respondents replied that they did it rarely. Whereas, 3 (18.75\%) and a single mentor (6.25\%) confirmed that they sometimes made and did not make formal discussions respectively. For the mentoring practice on the teaching strategies, $12(75 \%)$ and $4(25 \%)$ of the mentor respondents confessed as if they did it rarely and sometimes respectively.

Moreover, the results of the responses in the mentees questionnaire (see the findings under table 7 in the results section) and the interview conducted with EFL mentors, mentees, English language department heads, school supervisors and principals all affirmed the above fact that the consistent and organized support on psychological and instructional issues by EFL mentor teachers is not satisfactory and below the expected. However, Feimen - Nemser, (2001) recommend that mentees /lessexperienced teachers/ need to be supported regularly to improve their professional growth so that formal discussions on the 
subject matter, pedagogical issues and about teaching in general are useful means or tools to improve their practice in the course of their career. In addition, less-experienced teachers /mentees/ often lack the practical knowledge and experience of teaching as compared to the experienced ones /mentors/ (Feimen - Nemser 2001; Longdon et al., (2012) and they need to get the chance to learn from good teaching practices of experienced teachers (Wong, 2005). The best way to fill this gap, according to these researchers, is to set opportunities for mentees' to host classroom observations, to participate in lesson preparation, give advice for them in relation to how to cover the required subject matter, evaluate and report students' improvement and manage different requirements.

But the results gained from both mentors and mentees questionnaire generally showed that EFL mentors of the four schools have limitations in mentoring the less-experienced English language teachers on the different teaching practices (see the results under table 4 and 7 above). However, it would have been very nice if less-experienced English language teachers had got more feedback and guidance on the different practices in order to enable them to be watchful of the situations and decide on a style that satisfies the particular classroom situations and thereby develop their professional career.

Generally, from the above fact, one can infer that less-experienced English language teachers of the four comprehensive secondary schools have not got the two important areas of support, which Gold (1996) calls them saying instructional support (that comprises helping the less-experienced teacher acquire the knowledge, skills and approaches to be effective in the classroom and in schools) and psychological support (that includes providing advice, counseling, sharing experiences meant to improve the mentees' feelings about themselves and their capacity to cope with stress).

\subsubsection{Contributions Made by Stakeholders to Enhance the SBEM Program Practices}

As per the existing literature, mentoring is not something that can be left to chance rather it is usually assumed the organization is supportive for effective formal mentoring program practices to exist thereby professional growth and quality of education is to be brought. According to Lonnie, D. \& Crawford (2005), this can be done by giving on-going training for mentors and mentees, providing the time and resources necessary for the practitioners and constantly evaluating the mentoring process.

However, the results gained from sampled respondents via questionnaire and interview confirmed that the follow-up and facilities given for school based English mentoring program practices by stakeholders are not satisfactory and which are almost non-existent as concerned bodies hardly give attention to the program. For instance EFL mentor teachers were asked questions to know whether the school or school officials rendered the incentives and facilities so as to foster the school based English mentoring practices or not (item14, 15 and16 in table 6). Almost all (93.75\%) responded to item 14 that their school did not motivate the program by incentives. Moreover, while more than half of the mentor respondents $56.25 \%$ replied saying 'never' for item number 15 that they have not been assisted in facilitating the English mentoring practices with appropriate facilities by school officials $31.25 \%$ and only $12.5 \%$ of them responded saying that they have been assisted rarely and sometimes respectively.

With regard to mentor teachers training, item 16 of table 6 in the results section was provided for sampled EFL mentors to know how often they have been participated in in-service training opportunities. Hence, majority $75 \%$ replied saying 'never', while only $25 \%$ responded saying rarely. These figures indicate that EFL mentor teachers of the four comprehensive secondary schools are distant from ongoing training opportunities which are very important to help mentors get the necessary theoretical concepts and practical mentoring skills. In addition, the results which were gained from mentees' questionnaire and the findings gained from sampled interview respondents on the issues discussed above are almost consistent with the above facts ( see the results of item 10 and 11 under table 6 above and the interview results which are presented or discussed alongside the questionnaire items of both mentors and mentees).

These results point out as though little has been done regarding to the facilities and provisions rendered to the mentoring practices by the concerned bodies.

\section{Conclusion and Recommendation}

\subsection{Conclusion}

Based on the results, the following conclusions have been derived.

a. As part of the school level TDP, teachers are expected to develop their own capacities as an individual or as a group on a continuous basis so that this continuous professional growth of teachers is perceived as a means to achieve the school improvement program in the country. As the results of the study indicated, in practice, a lot remains to be done to create a learning community of EFL teachers who consistently improve their capacity on the subject matter and language teaching strategies and hence improve their schools. That is the school-based English mentoring practices in the target schools such as observing the mentee and providing feedback, assisting them with lesson plan preparation, classroom management, subject matter issues and teaching strategies by the mentor teachers were often less satisfactory. 
b. On the supporting conditions, a look in to the contents of chapter four confirmed that it is not targeted towards building practical and theoretical know-how that enable the EFL mentor teachers to effectively manage the SBEM program. The practice so far is that majority of experienced teachers serve as English mentors without the basic knowhow and skills on it. These data, therefore, imply that the existing training institutions do not fully support the English mentoring program is not fully supported by the existing training institutions. Because of this, most of the EFL mentor teachers of the sampled schools have basic gaps as to how to mentor their mentees effectively. School principals', supervisors' and English language department heads' support in facilitating and supervising the SBEM activities via different means to ascertain that less-experienced English language teachers' mentoring is on the right track in the target schools was rather weak. This is a weak link in teacher professional continuum and can only be strengthened when every stakeholders collaborates effectively (MOE, 2004; Reynolds, 1995; Zimpher \& Rieger, 1988).

c. In sum, the findings of the study have shown that the structured practice of school-based English mentoring by EFL mentor and mentee teachers is not satisfactory and in line with what the existing literature is concerned as the conditions necessary for high quality mentoring were affected by a number of constraints and did not always prevail in the schools.

\subsection{Recommendations}

Based on the findings of the study, the following recommendations have been given:

a. Provision of appropriate on-going training to key players is a pressing step to take to improve the frequency and quality of school-based English mentoring practices. The MOE, teacher training institutions (colleges and universities) and other concerned bodies should organize successive workshop, seminar and offer continuous in-service training opportunities so that EFL mentor teachers can get the chance to share experiences on how they practically mentor the less-experienced teachers. In relation to this, it may be important to quote what Moir (2006 p. 178) suggests:

Mentors are not born but made and therefore policy makers who advocate proliferation of mentoring programs without adequate support and resources for on-going professional development of both mentors and mentees undermine their policy goals of improving the quality of new teachers' practice.

Second, to effectively manage and support the SBEM practices, training should be organized for the school principals, supervisors and responsible WEB implementers of the selected schools.

b. From the results found and conclusions drown, the researcher would like to recommend for both EFL mentor and mentee teachers to make themselves ready for a change of their learning to teach away from learning in isolation by trial and error methods and move towards working collaboratively with their colleagues as this, in turn, can help them to find remedies to the difficulties they encounter and enhance their self-confidence and self-esteem in the classroom.

c. Finally, the researcher would like to suggest that because this study was only limited to four government comprehensive high schools of West Gojjam Zone, further research need to be conducted based on a greater number by taking participants from different schools, by adding some other variables like EFL teachers' attitudes towards the program since they are the cornerstone of this and many other school-based initiatives, and their views regarding such initiatives are critical for success in a different research design so that a detailed and comprehensive type of generalization can be made in the area.

d. As one can understand from this study, the majority of EFL teachers who are assigned to run the mentoring program did not receive special training in mentoring. How will the processes, practices and results of this program change when mentors are trained? This is another principal area for further research.

\section{References}

[1] Anderson, C. (1992). Visions of Change: A report of the Clinical Schools Project.ERIC Clinical Schools Clearinghouse, American Association of Colleges for Teacher Education. Washington D.C.

[2] Bolhuis, S., \& Voeten, M. J. (2001). Toward self-directed learning in secondary schools: What do teachers do?. Teaching and Teacher Education, 17(7), 837-855.

[3] Brooksfield, S. (1995).Becoming A Critically Reflective Teacher. San Francisco: John Willey and Sons Inc.

[4] Brown, J. D. (2001). Using Surveys in Language Programs. Cambridge, UK: Cambridge University press.

[5] Butcher, J. (2002). A case for mentor challenge? The problem of learning to teach post-16. Mentoring and Tutoring, 10(3), 197-220.

[6] Cohen, Manion\& Morrison, (2007).Research Methods in Education (6 ${ }^{\text {th }}$ ed.). London and New York: Tayler\& Francis e-Library.

[7] Collins, J. W. \& O' Brein, N. P. (eds) (2003). The Greenwood Dictionary of Education. West port: Greenwood Press

[8] Desta, D., Chalchisa, D., \& Lemma, G. (2013). School-based continuous teacher professional development in Addis Ababa: An investigation of practices, opportunities and challenges. Journal of International Cooperation in Education, 15(3), 77-94.

[9] Danielson, C. (1999). Mentoring beginning teachers: The case for mentoring. Teaching and change, 6(3), 251-57. 
[10] Donaldson, S. I., Ensher, E. A., \& Grant-Vallone, E. J. (2000). Longitudinal examination of mentoring relationships on organizational commitment and citizenship behavior. Journal of Career Development, 26(4), 233-249.

[11] Feiman - Nemser, S. (2001).From Preparation to Practice: Designing a Continuum to Strengthen and Sustain Teaching. Teachers College Record, 10 (6), 1013-1055.

[12] Feiman - Nemser, S. (2008).Helping Novices Learn to Teach: Lessons from an Exemplary Support Teacher. Journal of Teacher Education. 52 (1), 17-30

[13] Feiman-Nemser, S., Carver, C., Schwille, S., \& Yusko, B. (1999). Beyond support: Taking new teachers seriously as learners. A better beginning: Supporting and mentoring new teachers, 3-12.

[14] Gold, Y. (1996). Beginning teacher support: Attrition, mentoring, and induction. Handbook of research on teacher education, 2, 548-594.

[15] Hancock, B. (1998). An Introduction to Qualitative Research. University of Nottingham. Trent Focus group.

[16] Haney, A. (1997). The Role of Mentorship in the Work place.In M.C. Taylor. (Ed.), Work place education (pp. 211-228). Toronto, Ontario: Culture Concepts.

[17] Hargreaves, A. \& M. Fullan. (2000). Mentoring in New Millennium. Theory and Practice, 39(1), pp. 50-56.

[18] Jack C. Richards \& Thomas S.C Farrell (2005). Professional Development for Language Teachers. Cambridge: CUP.

[19] Kennedy, A. (2005). Models of Continuing Professional Development: A Framework for Analysis. Journal of In-service Education, 31(2), 235250.

[20] Koc, E. M. (2012) Idiographic Roles of Cooperating Teachers as Mentors in Pre-service Distance Teacher Education. Teaching and Teacher Education, 28/6/, 818-826. http://dx.doi.org/10.1016/j.tate.2012.03.007

[21] Kochan, F. K. (Ed.). (2006). Global perspectives on mentoring: transforming contexts, communities and cultures. IAP.

[22] Longdon, F. J., Alexander, P. A., Dinsmore, D. L., \&Ryde, A. (2012).Uncovering Perceptions of Induction and Mentoring Experience: Developing a Measure that Works. Teacher Development, 16(3), 399-414.

[23] Lonnie D. Inzer\& C. B. Crawford (2005).A Review of Formal and Informal Mentoring: Processes, Problems and Design Journal of Leadership Education, 4(1).

[24] Malderez, A. \& C. Bodoczky. (1999). Mentor Courses. Cambridge: CUP.

[25] Malderez, A. \&M. Wedell (2007). Teaching Teachers: Processes and Practices. London: Continuum

[26] MENTOR/ National Mentoring Partnership (2005). How to Build a Successful Mentoring Program Using the Elements of Effective Practice: The United States of America. Available from www. Mentoring .org. [Accessed on 12 ${ }^{\text {th }}$ May 2015].

[27] Ministry of Education (1994).Education and Training Policy of Ethiopia. Addis Ababa.

[28] Ministry of Education (1998).School improvement Training Manual. A.A: EMPDA.

[29] Ministry of Education (2003).The Teacher Education System Overhaul (TESO) Program Policy Document. Addis Ababa: MOE.

[30] Ministry of Education (2004).Education Sector Development Program. Action Plan. Addis Ababa: EMPDA.

[31] Ministry of Education (2005c).Guidelines for English Language Enhancement in our Teacher Education Institutions: A set of Practical guidelines to help promote the use of English.The ELIP Cascade.

[32] Ministry of Education (2007a).Ethiopian Teacher Development program: Blueprint. Addis Ababa: EMPDA.

[33] Ministry of Education (2008).General Education Quality Improvement Package. Addis Ababa: Mega Printing Private Ltd. Company.

[34] Ministry of Education (2009b).Continuous Professional Development for Primary and Secondary Teachers, Leaders and Supervisors in Ethiopia: The practical toolkit. Addis Ababa

[35] Ministry of Education (2012). Hand Book for School Based English Mentoring for Primary and Secondary Teachers. Addis Ababa.

[36] The First Ethiopian Mentor Trainer Team.(2012). School Based English Mentoring Guide For Mentors of Secondary School Teachers of English.TELDD/ELIQIP.

[37] Moir, E. (2006). Mentors in the Making. Teachers College, New York: Columbia University Press.

[38] Richards, J. C., \& Farrell, T. S., C. (2005). Professional Development for Language Teachers: Strategies for Teacher Learning.Cambridge: Cambridge University Press.

[39] Richards, J. C., \& Lockhart, C. (1994). Reflective Teaching in Second Language Classrooms. New York: Cambridge University Press.

[40] Scott, N. H. (1999). 'Supporting New Teachers: A report on the 1998-99 Beginning Teacher Induction Program in New Brunswick'. ERIC Document Reproduction Services No. ED 437347.

[41] Solomon Geda. (2001). Some Insights in to the Mentoring Role of High School Teachers. http://hdl.handle.net/123456789/4058.

[42] Successfulmanagers.com. Counseling and Mentoring.Mentoring Management Concepts. Retrieved from www.successfulmanagers.com/6675/71 issue/concepts 1-71 issue.htm.

[43] Tadele Zewdie. (2013). Teacher Induction and the Continuing Professional Development of Teachers in Ethiopia: Case studies of three first year primary school teachers. Unpublished thesis

[44] The Alberta Teachers' Association (1998). Mentoring Beginning Teachers.

[45] Veenman, S. (1984). Perceived Problems of Beginning Teachers. Review of Educational Research, 54 (2), 143-178.

[46] Woubshet, H. (2006). Factors Affecting the Implementation of School-based mentoring in pre-service teacher education: The case of students of the language stream at Kotebe College of Teacher Education and St. Mary's University Colleges' Practicum. 